万劺に

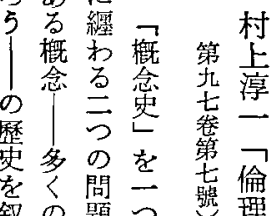

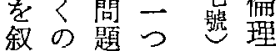

浦場をの 的

于合指方 自

る 摘法、律

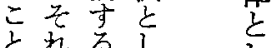

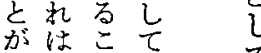

、現亡 考

何代方关

よ

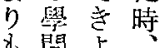

b閣

ま 5 差治

、基 郎 當

當礎ら り

該 概、

概 念 第

念で心 方

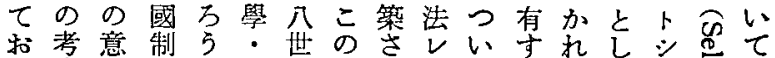

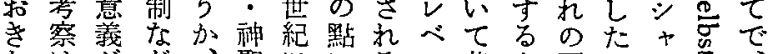
たはがど、聖ににるル若と國こフ た

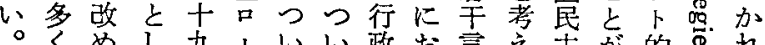

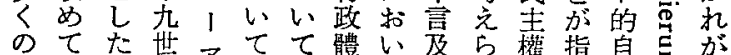
示問方紀、てて體い及ら權指自晋加

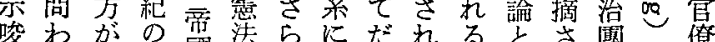

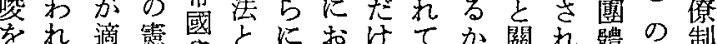
與て切法領い論いでいら連て繥理的 えいな概邦 5 領てなるでしい國念後

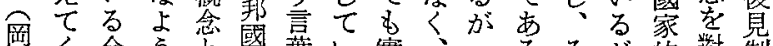

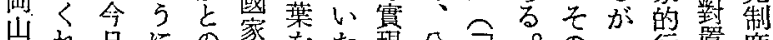

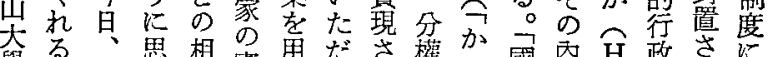

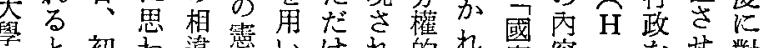

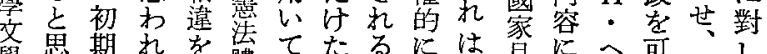

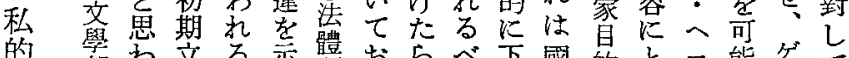

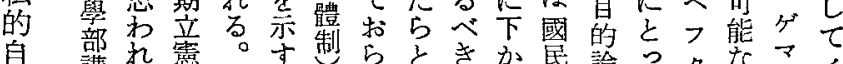

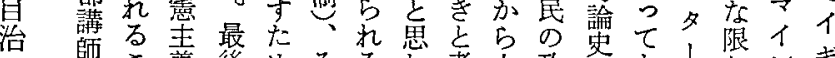

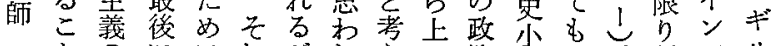

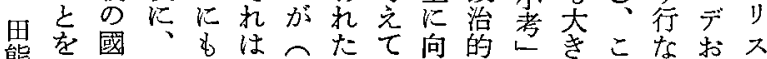

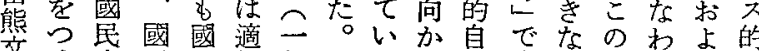
文け主民法切般立たっ治自意こせびな

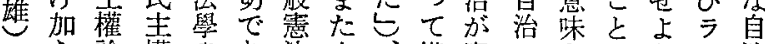

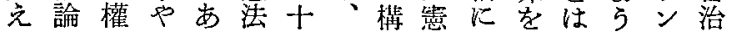

れぬ先る口史售で，の的と言史の史々人すとしれの形

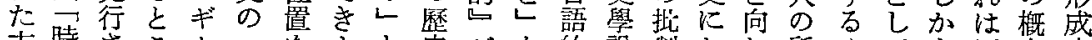

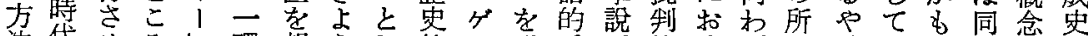

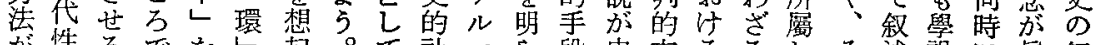

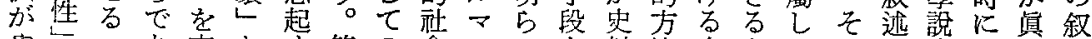

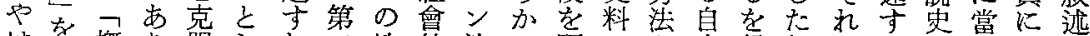

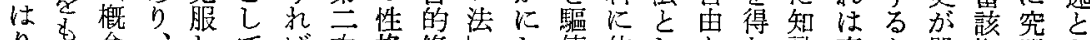

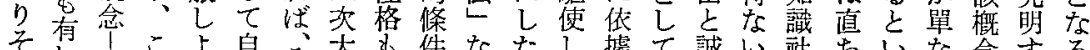

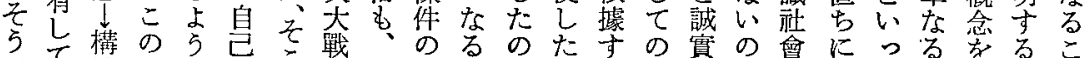
でて活點と竞こ戰子尗のた守の惯の會にっるをるこ あい些點李位で後々下梠で構る切四で學た特軸にと

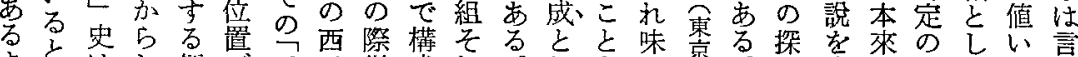

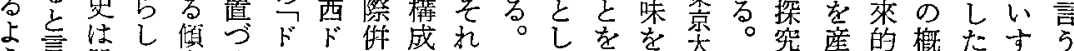

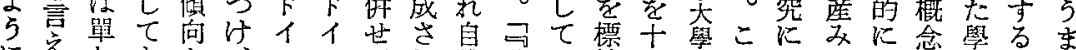

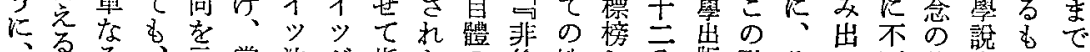

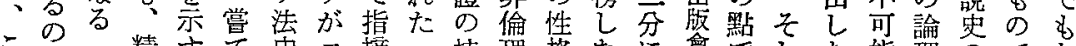

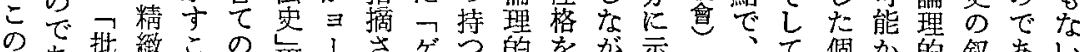

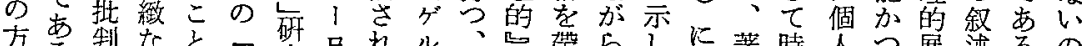

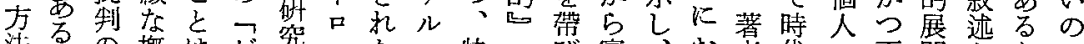

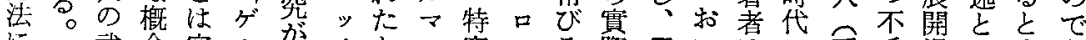

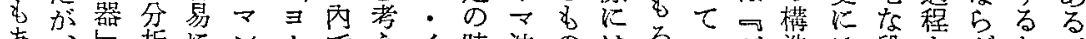

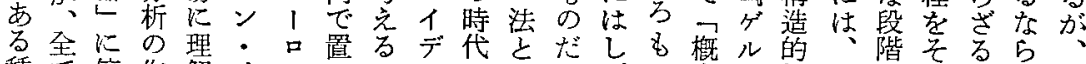
種て停作解イッかこオのうっばろ念マ把そをれをばも

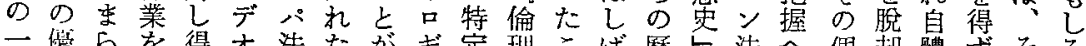

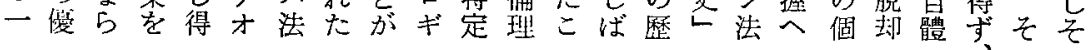




\section{書 誘}

の體名ピフ はずいそさる的無すなに問明ヨとれるし面

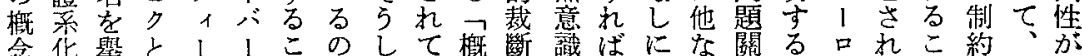

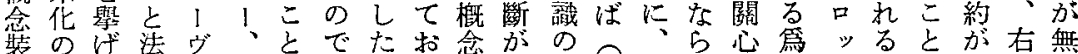

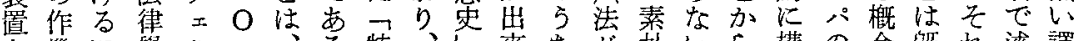

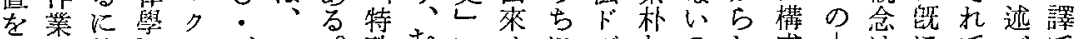
各に停らのブこ。殊むにせにグなのし成|㤝にでへで

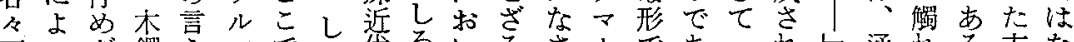
再っざ鐸らンで吕代ろいるざであうれし通れる方な 棈てる塑つナのし的即てを狆テ過る重たと常た高法い

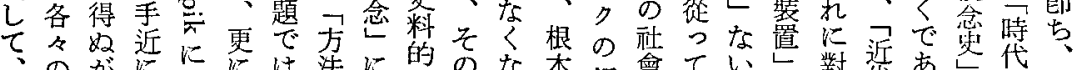

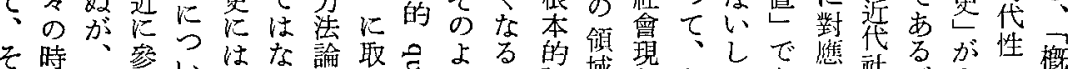

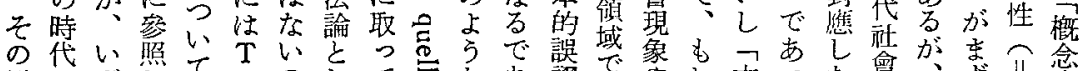

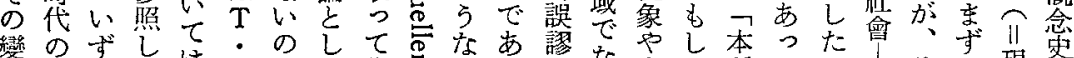
遷各れ得は

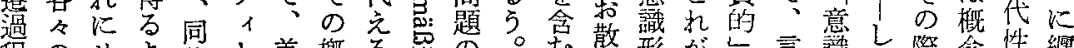

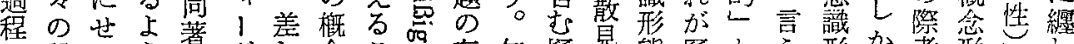

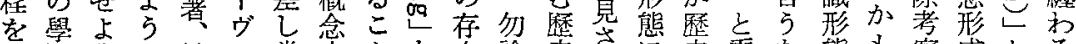

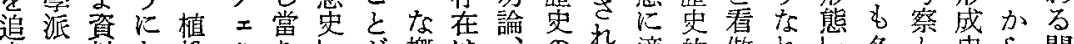

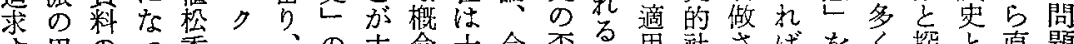

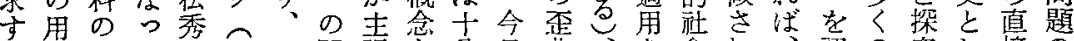

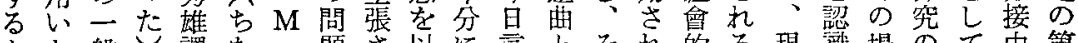

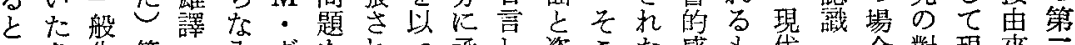
い各化等っみヴをれっ承わ恣こた感も代・合對現來二

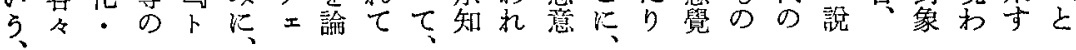

そル濟なっし著律 一追とでして念つ極自とは秘ゆ語

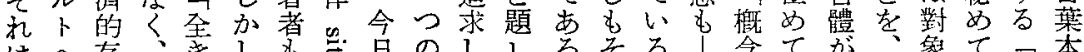

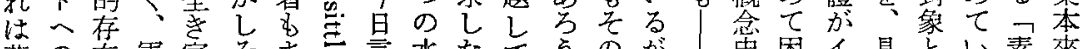

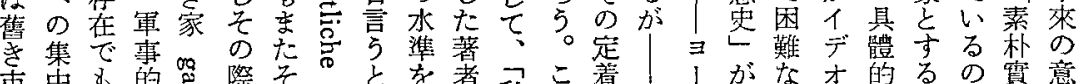

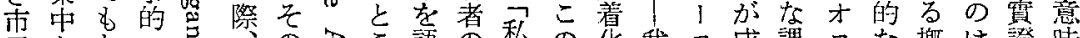
民とあ:造莎怘語の私の华我口成課口な概は證味 社い口宗品著叙吉万る的點が國 立題ギ達念事圭で

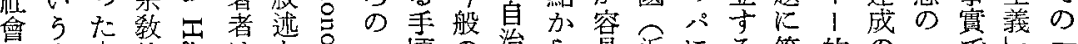

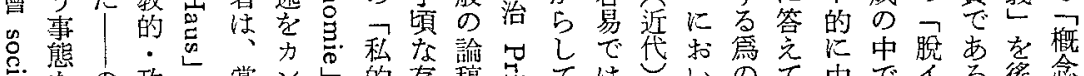

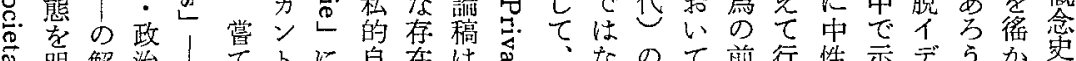

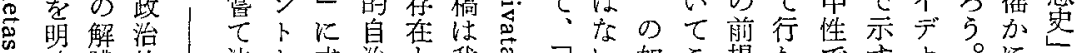

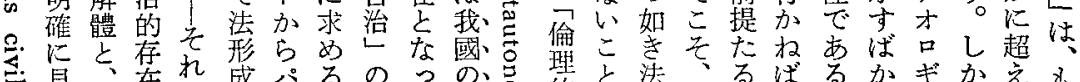

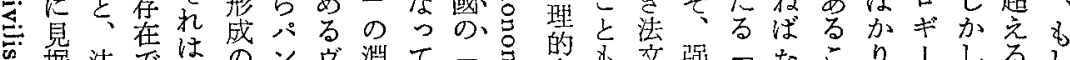

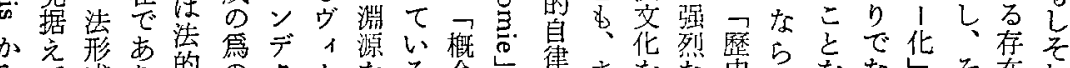

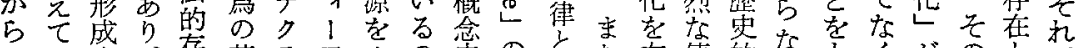

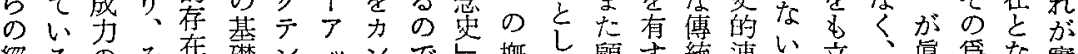

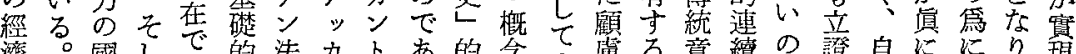

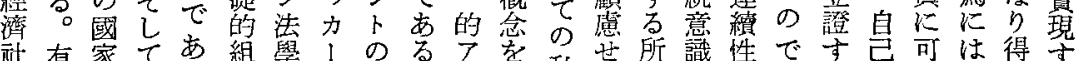

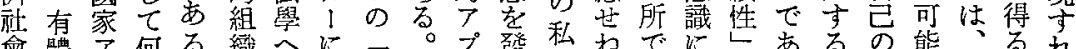

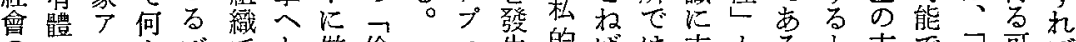

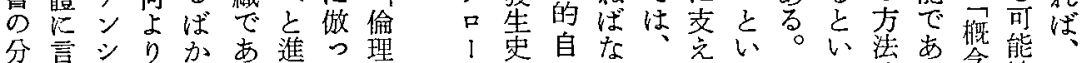

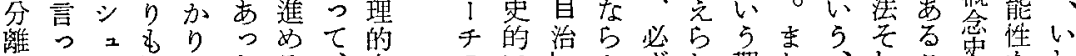
とてタ經でたる。回のに好ずれ觀た、机英をわ 


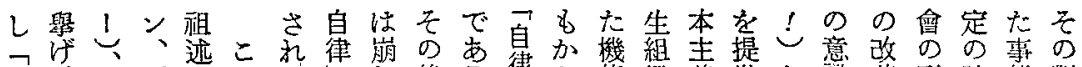

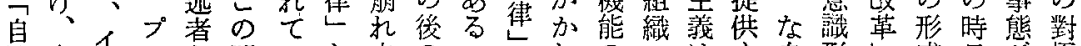
治各 1 ᄀ

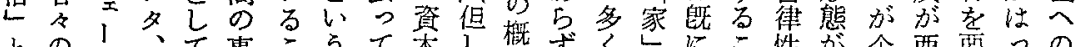
との、て事こ代て本し念ずくしにこ珄が企西要のの

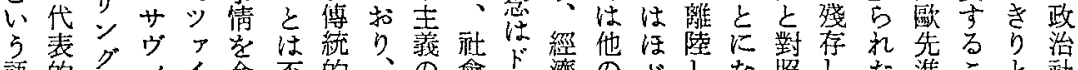

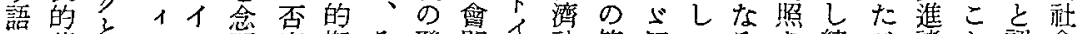
の著々

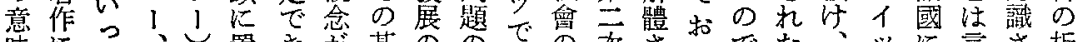
喿につ、置きが基ののでの次さりでた、ッに言さ析

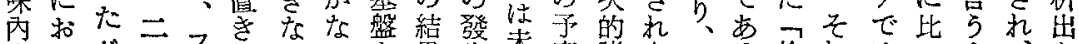

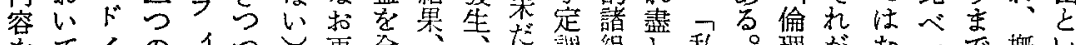

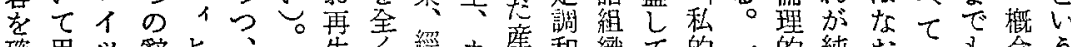

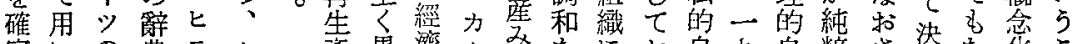

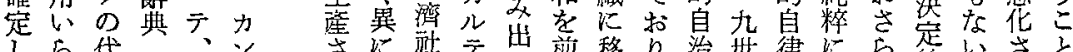

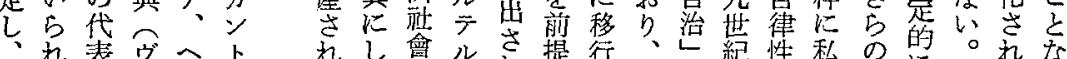

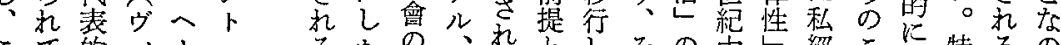

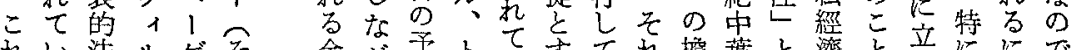

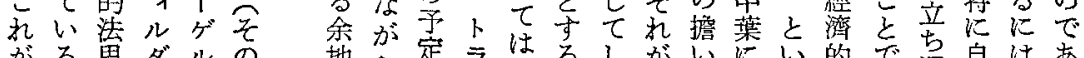

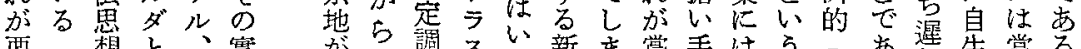

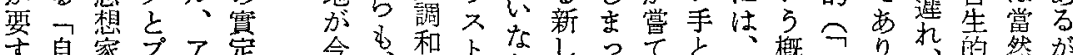

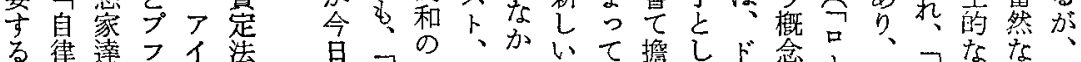

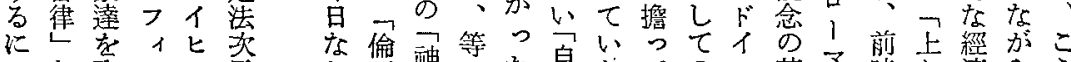

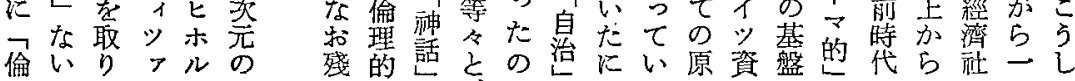

息民獲えそのの治所構有治しで認有手て全がンカ

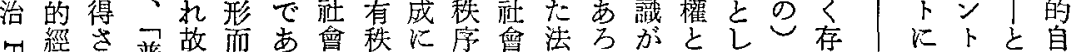

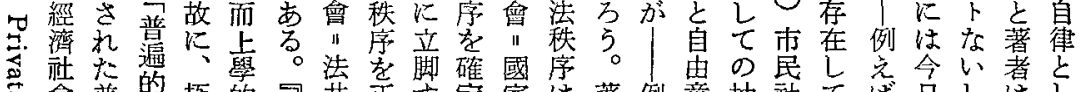

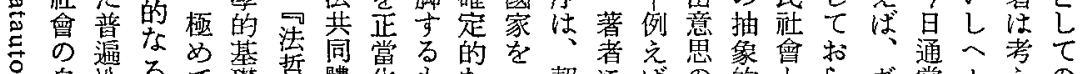

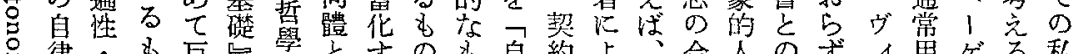

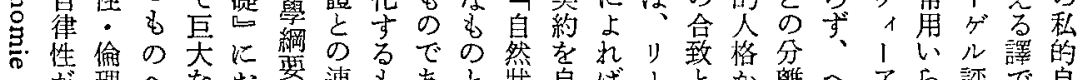
なが理へな怙連もあと狀自ば、とか離へフら評で自

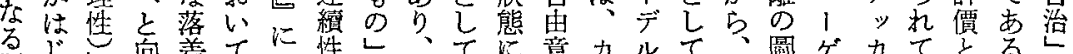

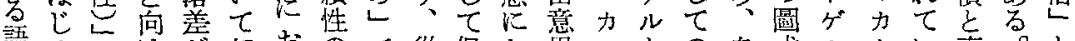

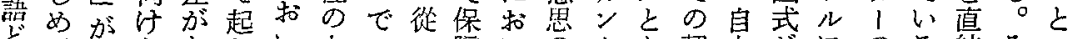

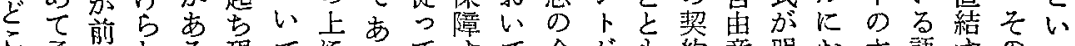

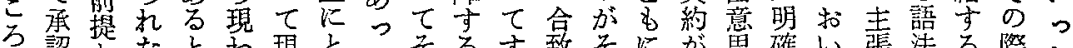

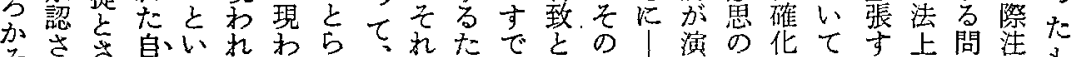

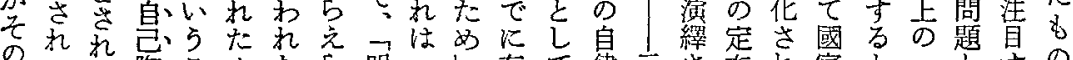

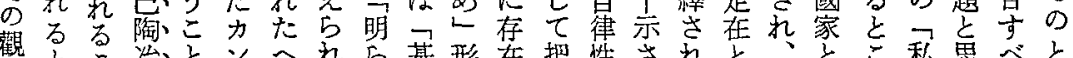
念とこ治とンへれら基形在把性されと私思心と

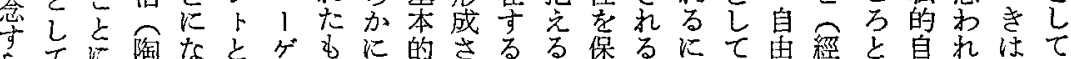

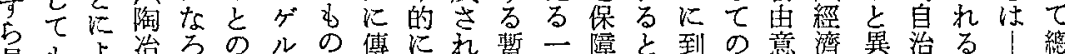

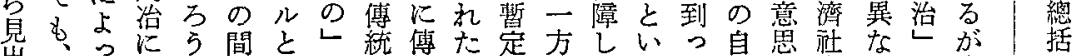

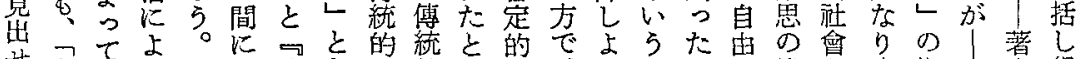

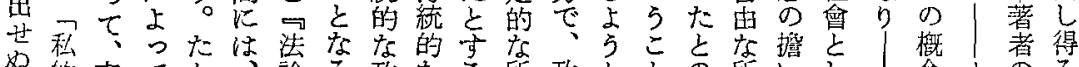

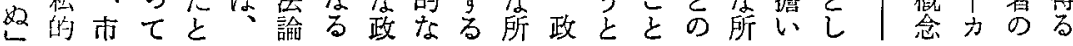




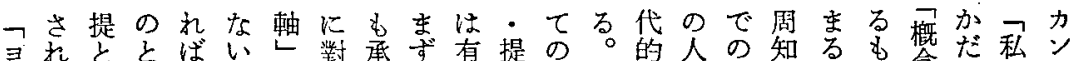

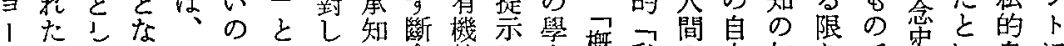
口文てうこでしての念的し者概私の南如りで串い自に ッ字、得れ亦ては事せにてな念的精意くであとう治比

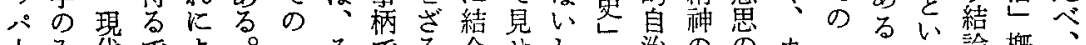

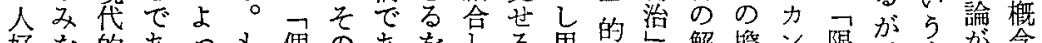

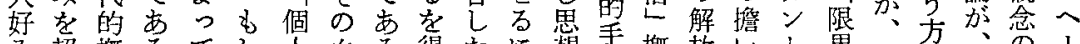
文賴概万てし人血万得たに想手概放い上界し法々の

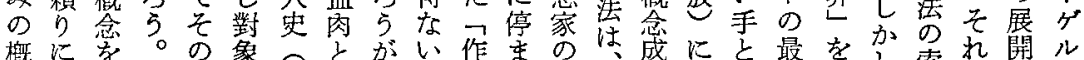

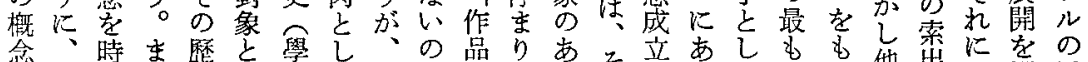

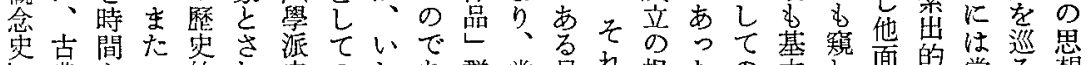

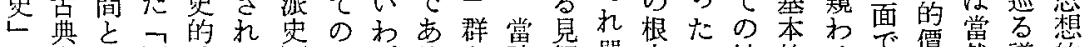
に克空㷴社たし膨ばると該解單本の抽的せで㵋然議的

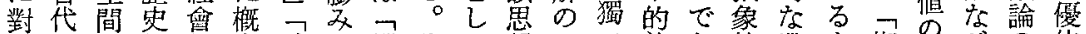

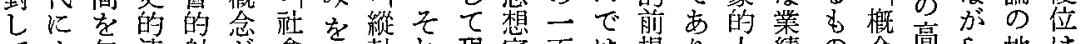
七ま無蓮射肪會む軸机現家面は提り人績の念高ら地は

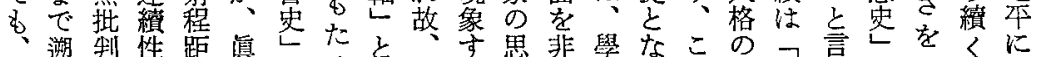

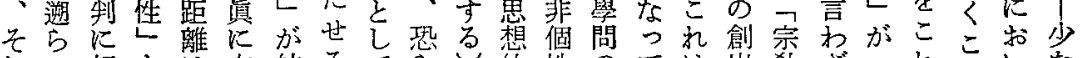

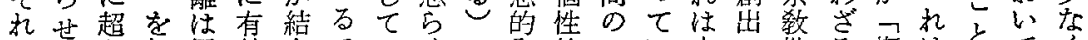

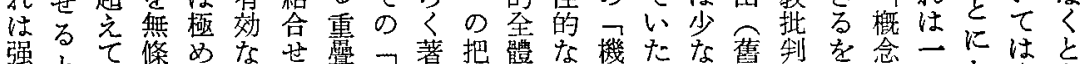

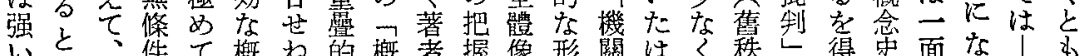

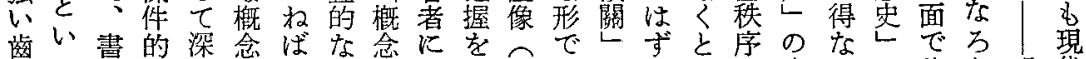

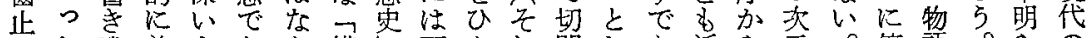
めた殘前もあら横百と開しあ近ら元。停語。らの

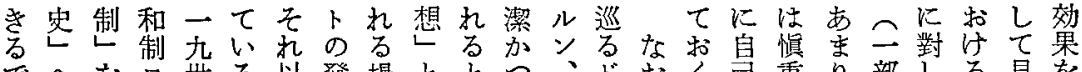

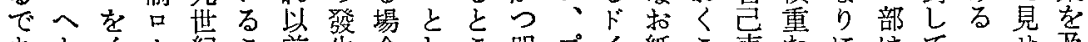
あとイ、紀こ前生合しこ明プイ紙こ表たにはててせ及

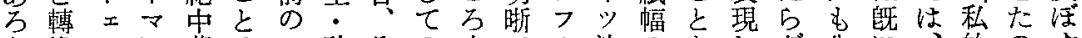

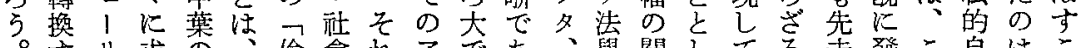
。すり求の、倫會机了であ、學關してる走發こ自法こ

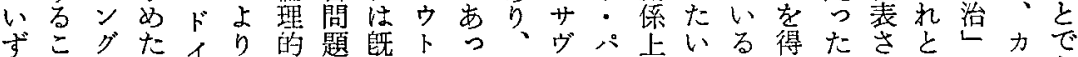

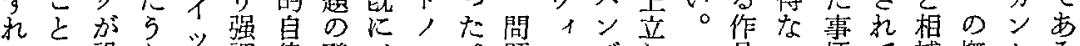
にに說え音調律發ドミ。題二デ方品い柄て補概卜ら

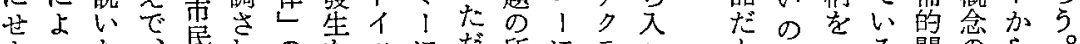

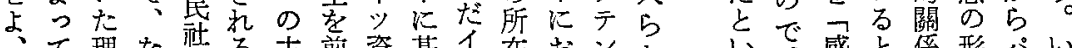

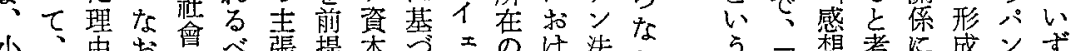
小、由拈會べ張提本づェのけ法が梖考に成ンず

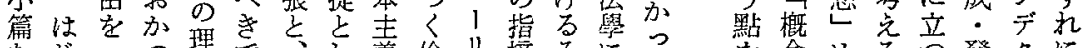

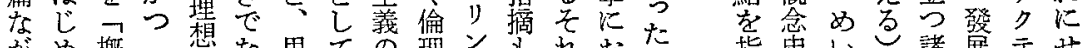

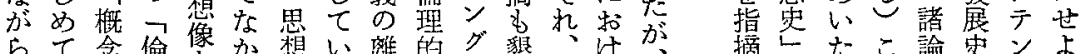

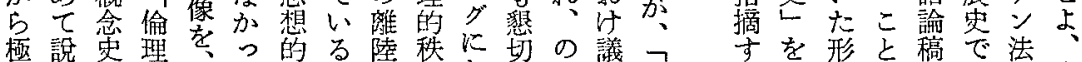

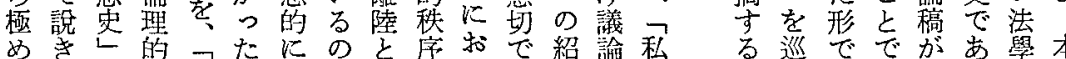

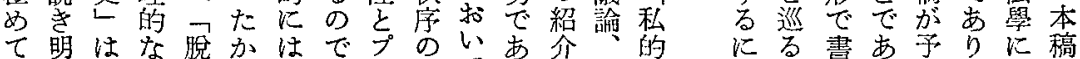

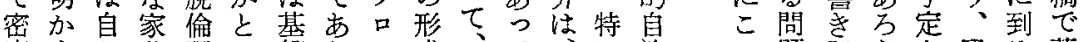
度す加父理の盤りレ咸方て、治こ題記

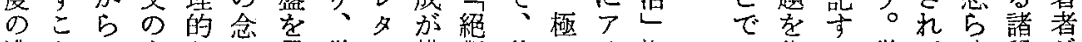

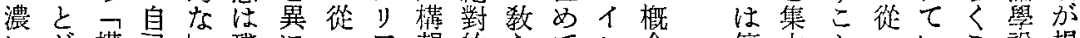

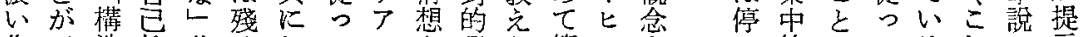

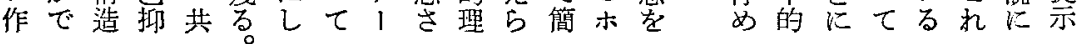




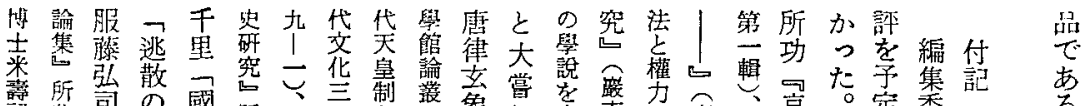

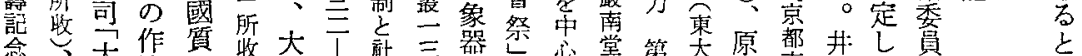

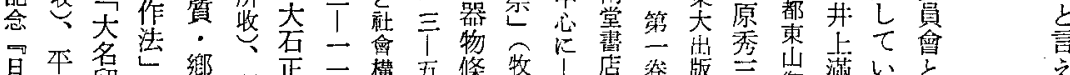

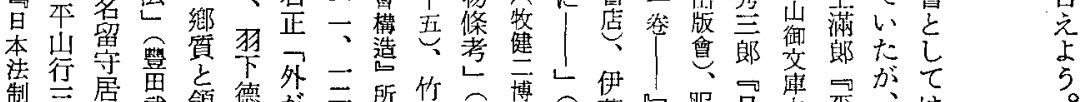

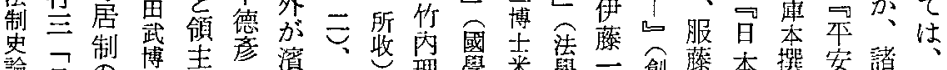

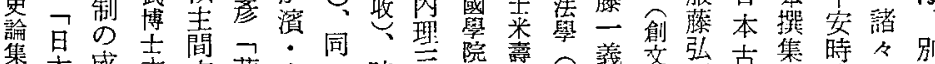

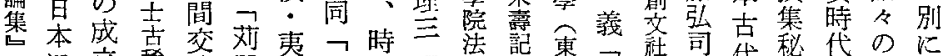

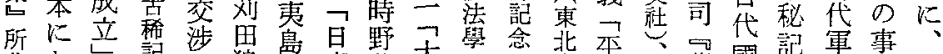

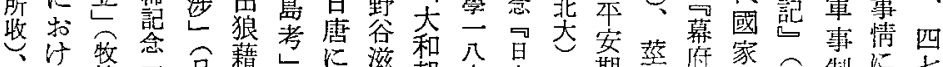

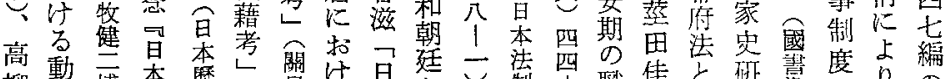

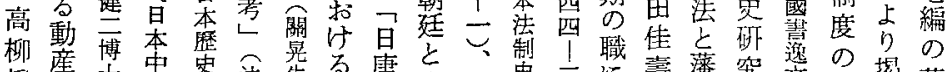

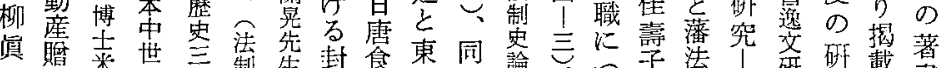

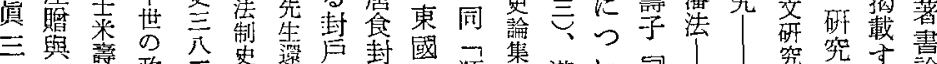

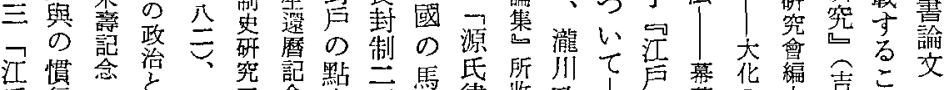

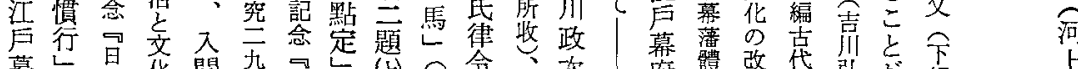

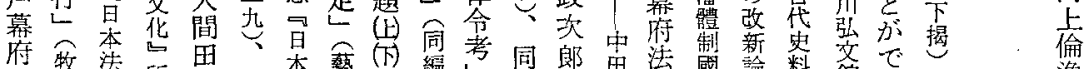

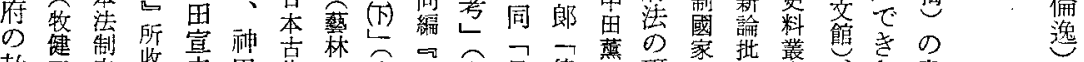

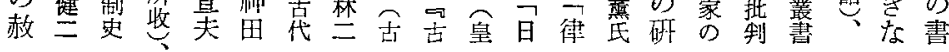

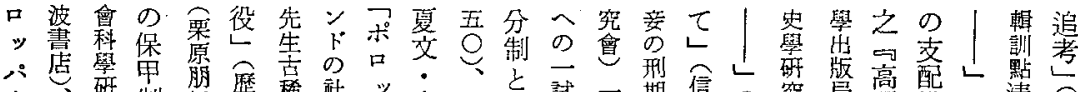

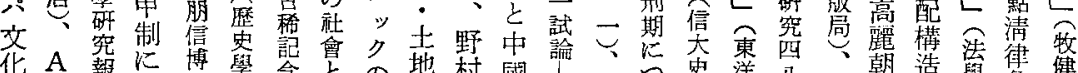

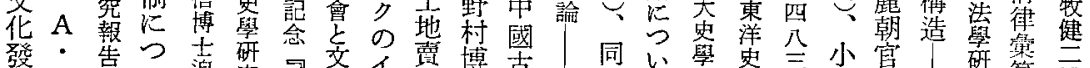

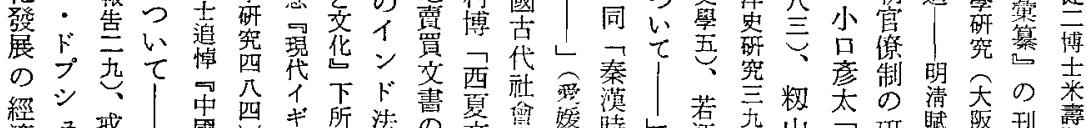

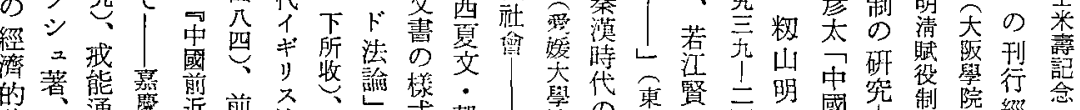

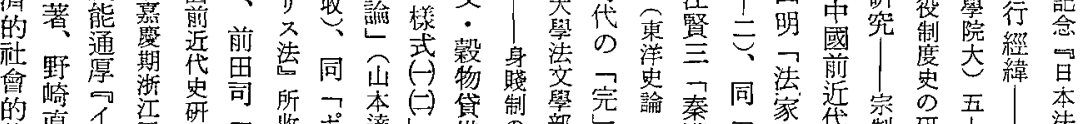

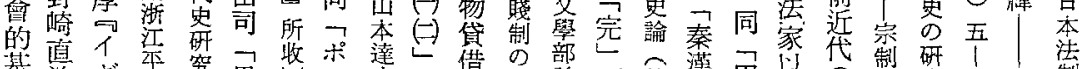

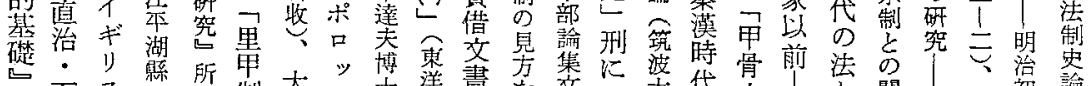

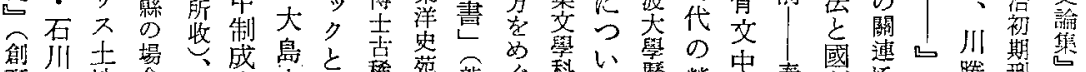

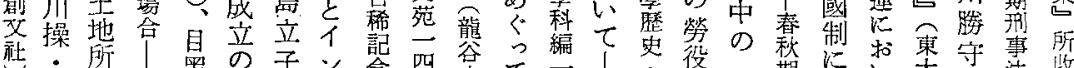

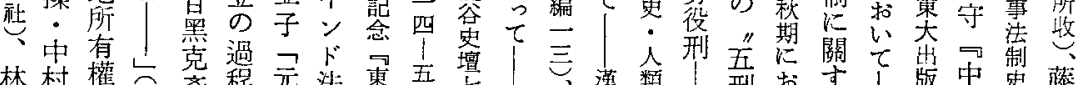

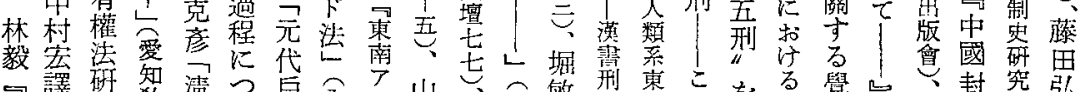

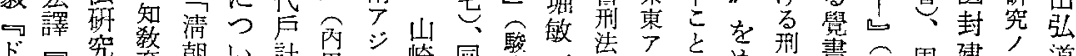

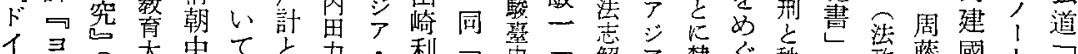

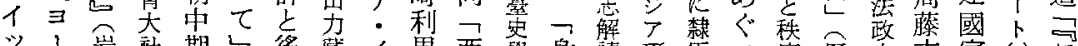

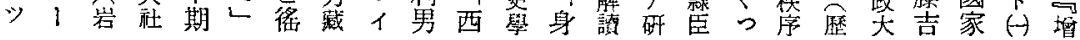

